\title{
CRITICAL ANALYSIS OF THE INFLUENCE OF \\ TRANSNATIONAL CAPITALISM ON INSTITUTIONS AND \\ ORGANIZATIONS
}

\section{ANÁLISE CRÍTICA DA INFLUÊNCIA DO CAPITALISMO TRANSNACIONAL SOBRE AS INSTITUIÇÕES E ORGANIZAÇÕES}

\author{
José G. Vargas-Hernández \\ University of Guadalajara - Jalisco - México
}

\begin{abstract}
This paper aims to analyze the development of capitalism and its influences on institutions and organizations from its beginnings to reach the highest stage in the processes of neoliberal economic globalization and the New Economy version with support of information and communication technologies. In raising this development from a critical analysis, it examines the impacts and effects on individuals, communities and the nation state. Subsequently it is questioned the scope of the imposed transnational neoliberal capitalism model. Finally, it is concluded that it needs a cultural transformation for not accepting the forms of domination, power and alignment of globalizing capitalism and to reconstruct the identity of communities through individual action and asserting collective self-determination, independence and self-management.
\end{abstract}

Keywords: Capitalism, institutions, organizations, transnational capitalism.

Resumo: Este artigo por objetivo analisar o desenvolvimento do capitalismo e suas influências sobre as instituições e organizações desde seus primórdios até o estágio mais elevado nos processos de globalização econômica neoliberal e a versão da Nova Economia, com o apoio das tecnologias de informação e comunicação. Ao realizar este desenvolvimento a partir de uma análise crítica, ele examina os impactos e efeitos sobre os indivíduos, as comunidades e o Estado-nação. Posteriormente, é questionado o alcance do modelo imposto pelo capitalismo transnacional neoliberal. Por fim, conclui-se que é preciso uma transformação cultural para não aceitar as formas de dominação, poder e alinhamento do capitalismo globalizante e reconstruir a identidade das comunidades através da ação individual e coletiva afirmando a autodeterminação, a independência e a autogestão.

Palavras-chave: Capitalismo, instituições, organizações, capitalismo transnacional.

\section{THE EMERGENCE OF CAPITALISM}

The term capitalism carries an old history of human exploitation, and for a long time, in general, has been omitted from the speeches, although it is accepted the existence of a system that in fact is valid and current with important variations (Jay and Jay, 1986; Tormey, 2012). Weber (1978) defines the spirit of capitalism as the set of elements that inspire ethical entrepreneurs on their shares in favor of capital accumulation. Thus, capitalism establishes a new moral relationship between people and their work.

The phenomena of economic globalization have had an evolutionary process. Capitalism is an evolutionary process that is touted as an engine of economic progress and development. Economists such as Marx analyze the 
evolutionary process of capitalism using the dialectic method to describe the negative influences of the modern capitalist engine on labor relationships in industrial organizations created by the economic -based structures. Schumpeter analyzes the innovation and scientific advance supported by a continuous process of creative destruction as the result of technical and technological relationships among with institutional and organizational structures (Nelson, 1990).

The evolutionary processes of capitalism have lasted several centuries and have been inherent in the processes of economic globalization, which in turn are the result of processes of capital accumulation. The two shock waves of capitalism inherent to imperialism, took place after the conquest of America and the Industrial Revolution (Amin, 2001). In this first phase of economic globalization a mercantilist system develops but it was opposed by the liberation forces of some colonies such as the British-American, and later the Spanish-Latin-American, the French-American and the Portuguese-Latin-American that defy the logic of production. Capitalism proclaiming freedom overcame unjust economic relations of feudalism but became the justification for the looting of the resources of the less developed peoples for the benefit of the colonial metropolis. The colonial legacy has marked the economic, political, social and cultural rights of colonized peoples giving rise to institutional and organizational relationships and sense of identity.

The Reformation represented a break in confusing ruling classes of their time with the feudal past that according to Weber laid the ideological foundation for the development of capitalism between the emerging bourgeoisie, large landowners and the monarchy that kept under control the threat represented by the poor farmers, the main victims of social transformations. The concurrent rise of capitalism with the phenomenon of modernity separates the political sphere from the economic one. From this alternative perspective, modernization was the wellspring of Western capitalism whose ideological forays into the world kept it in a constant delay.

However, the development of capitalism as an economic system has degraded social development, specifically among those who do not have capital and have to hire their work and also at macro level among colonial territories and less developed countries (Wallerstein, 2001; Thomas, 1980; Mooers, 1991; Grosfoguel and Cervantes-Rodríguez, 2002 and Dietererich, 2002). The economic development of England was based on the thesis of classical political economy developed by the English Adam Smith, Thomas R. Malthus, David Ricardo and the Frenchman Jean Baptiste Say based savings, work and free trade. But the application of these theories is contradictory and incompatible with the systematic use of political, military and economic development in praxis of colonialism, exploitation of protectionism and barbarians (Dietererich, 2002).

The monarchy European feudalism in the eighteenth century is resisted and destroyed by capitalist production forms and illustrated movements of the nineteenth century (Wallerstein, 2001; Thomas, 1980; Mooers, 1991; Grosfoguel and Cervantes-Rodríguez, 2002 and Dietererich, 2002). The emergence of capitalism in the late eighteenth and early nineteenth century due to the use of new technologies such as the steam engine and new means of transport such as 
rail, accelerate the production and trade of the economy and generate enrichment for those who might benefit from these technical advances.

Since then, the capitalism become over time until these days in an increasingly oppressive system of capitalism legitimated by economic liberalism justifying mechanisms influencing institutions and organizations. These mechanisms deprive workers of their means of production. The new owners of means of production deliver their material and intellectual energies in exchange to a wage always less than the actual value of the goods produced.

Friedrich List, creator of German state capitalism in the late eighteenth and early nineteenth centuries, criticizes the double standard of the English moral. This criticism is synthesized in the analysis of Dietererich (2002) because since the constitution of the modern English state in the developmental dictatorship of Oliver Cromwell as was manifested in the Navigation Act (1651) and the monopoly of the East India Company to the days of the charming Tony Blair, the only real economic growth policy was the protectionist state capitalism (Robinson and Harris, 2000, Mann, 2001-2002). Blair's New Labour government framed by the notion of Competition State adopted a centre-left political strategy to achieve its own economic, social and political objectives (Cemy and Evans, 2004;Cemy and Evans, 2000).

\section{EXPANSION AND CRISIS OF CAPITALIST IMPERIALISM}

The second phase of the expansion of capitalist imperialism began with the industrial revolution, which deepens the polarization that has increased inequality and causes confrontations between the imperialist powers, socialist revolutions and national liberation revolutions that arise in the periphery. Marxism is a dialectical approach to the development of humanity. An approach from historical materialism mark the class struggle of capitalist development that evolves to a socialist society composed of a system of production, distribution and consumption consisting of equal individuals in a democratic State.

The logic of capitalism is the dominant ideology in the West since the Industrial Revolution (Lovins, Lovins, and Hawken, 1999) and was promoted heavily in the nineteenth century, based on the accumulation of capital by maximizing profit. The period between 1860 and 1900 is often referred to as the Second Industrial Revolution due to the large number of technologies invented during that time. Those who do not benefit do form a new social class that requires a socialist ideology to oppose capitalism which has its peak in the nineteenth and twentieth century (Chase-Dunn, 2001).

Since the 1929 crisis, the greater challenges that the capitalist system has faced are attributed to liberalism for its confidence in the ability of market mechanisms to overcome economic crises and passive assistance of governments. Reactions to the crisis in confidence condemn the free market. Keynes challenged capitalism to be the best policy for capitalists when he said that full employment is necessary for capitalism to grow and can be achieved only if governments and central banks intervene to increase 
Social welfare policy focuses on state responsibility for providing de commoditization of social benefits on the basis of principles of universality, equality and global coverage. This welfare model is incompatible with the urgent progress of unregulated capitalism, to which adaptive pressures, social welfare orientation of social democracy have redirected actively applying resources and services to young families.

Competitive capitalism became monopoly capitalism during the decolonization processes that occurred in the nineteenth century to strengthen global expansion after World War II through processes of capital accumulation and reproduction (Grosfoguel and Cervantes-Rodríguez, 2002). During the process of decolonization, the name of Third World countries was assumed by the "nonaligned" with the two large hegemonic blocks, socialism and capitalism, so that Latin America was not included. The national liberation movements after World War II end with a system of colonialism. However, the colonial legacy marked the economic, political, social and cultural rights of colonized peoples. These movements joined ethnic and religious communities against capitalism as a common enemy. When national popular movements are strong, they transcend in solidarity internationalism.

\section{NEOLIBERALISM AS AN IDEOLOGY OF CAPITALISM PULSE}

Neoliberalism is imposed as the best alternative to the exhaustion of expansive growth period of greater global economy after World War II, between 1940 and 1970. The economic model based on industrialization by import substitution was exhausted in terms of supporting economic growth. This period was considered as the "golden age of capitalism" with a high global economic growth characterized by industrial expansion of capitalist periphery countries and the strengthening of the economies of the socialist countries.

Globalization processes intensified after World War II with the creation of global institutions as expressions of the transformations undergone production, information and communication systems. The WTO is the successor to the GATT which together with other institutions like the International Monetary Fund and the World Bank emerged after World War II seeking to establish a new world order in global turbulent transition times by the unilateral imposition of capitalism.

Most developed countries promoted these international organizations to ensure their economic interests, hegemonic-based in free trade by promoting a devourer mercantilism under globalization processes with imperialist vocation. These international organizations can grant subsidies and tariffs that benefit only the powerful against the dispossessed and leading to nationalism of the developed world. Thus, globalization represents the most advanced stage of capitalist development which benefits economic elites through global integration processes supported by the doctrine of neoliberalism as an economic and political ideology.

The concept of globalization is ambiguous and it tries always expressing the empirical evidence. The concept of globalization began to be used for academic purposes in the mid-eighties. In any case, the concept of globalization should be 
reviewed from the ground, as the content and processes that characterize the development of global capitalism and contemporary societies (Aguirre Rojas, 2000). The evolution of transnational capitalism or neo-capitalism has resulted in economic globalization, which in terms of Márquez Ayala (2001) is based on four pillars: first, the ideology that exalts the market; second, the brand is neoliberalism, three, the theoretical is monetarism and four, its slogan is the hope of the village collective access to global prosperity and welfare.

The development in globalization has generally been capital-centered because it places capitalism in the center of the narrative development, thus tending to devalue or marginalize any possibility of non-capitalist development. The naturalness of capitalist identity as a template for all economic identity can be challenged (Gibson- Graham, 1996:146) for various economic development options proper of post development that value the same local models not necessarily complementary, neither opposing nor subordinated to capitalism. The term global village was coined in 1960. The neoliberal model of globalization that seeks to build a global village with global citizens, contradicts itself when it proclaims the opening of borders and the strengthening actually reinforce the essential role of national states.

Other historical interpretations (Reich, 1998) on the development of globalization processes dated to the end, more than half of the seventies and early eighties. These analysis point concurrent events such as the cumulative impact of the second oil crisis, a substantial decline in GDP, rising inflation rates, the traumatic event of the hostages in the U.S. embassy in Iran, the rise to power of Thatcher in Britain, Reagan's U.S. and Kohl in Germany. These events have resulted as part of the impacts of economic globalization processes.

From the eighties, the rise of the conservative right with Thatcher came to power in England, with Reagan and the Republican Party in the United States, and then fully assaulting power with Bush and the Falcons with their reactionary policies imposed unilaterally, dismantle the welfare state. This dismantle can lead to social disaster and jeopardizes not only the world order but the very survival of the capitalist system.

Neoliberalism is defined as the mode of governing through individual freedom that requires people to be free and self managing in different economic, social and political spheres of everyday life in health, education, bureaucracy, the professions (Ong, 2007).

Neoliberalism as hegemonic model of global capitalism was assumed and promoted by Thatcher in Britain and Reagan in the United States with the support of international financial institutions, the International Monetary Fund, the World Bank and the World Trade Organization, who promote policies economic and financial liberalization, deregulation, privatization, opening up of economies to the world market, precarious employment relationships and retraction of state presence in the economy. The manifestations of this development of emerging capitalism fall into the paradox which is that while focusing on self-regulatory role of market mechanisms, on the other hand triggers reactions to counter and offset the perverse effects of market mechanisms. 
The processes of creative destruction of capitalism, according to Schumpeter (1994), more accurately explain the development of international capitalism in its highest stage, globalization. The neoliberal interpretation of Hayek (1975) that the employer, under its responsibility, decides which produces, what services offers and how it does it in business activities, it's totally free. Consumers, meanwhile, are free to choose, according to their income, between values and services offered by the employer.

The socialist system was not ready to compete with the creative destruction processes of global financial capitalism that promises prosperity for all. Financial crises are a sign that the capitalist system is in constant transformation and creative destruction, such as the case of the oil crisis of the late seventies, the crisis of globalization in the nineties and the crisis of 2007-2008, no matter where those who harm while benefiting big business. The ideology of neoliberalism was pushed around the globe condemning all public action coming from the nation-state, transferring ownership of public assets to private and employing military intervention to defend their interests. The economic-political elite and their agents are campaigning to legitimize neoliberal ideology of transnational capitalism that promotes free market.

\section{GLOBALIZATION, THE HIGHEST STAGE OF CAPITALIST IMPERIALISM}

Transnational capitalism builds a system of institutions that overcome the structures of the nation state, exceed their functions, facilitate networks of supranational integration between groups belonging to the same stratum, reconfigured global social forces and dominated groups and dominant groups deepening global divide between those who benefit from globalization processes and those without.

However, the globalization of economic activities is promoted by governments, business and other groups. Everyday life changes and makes new systems and transnational forces, transforming the institutions of the societies we live in and has to do with the rise of individualism (Tepoztlán Center, AC. 1999). The emergence of this individualism is due in part to competition extends to the same individuals and is worrisome because it can determine the level of latent authoritarianism inherent in capitalism. Capitalism emerged as the result of individual liberal freedoms to guarantee individual legal and political equality. However, advanced capitalism has become quite adaptable and compatible with authoritarianism with policies suppressing individualism and intellectual freedoms.

This competitive individualism is the foundation of economic crisis of the globalization system. Soros (2002) argues that by stating that the public interest benefits by allowing people to pursue their personal interests, market fundamentalists have blurred the distinction. Those who adhere to this ideology of convenience have no qualms about bending the rules to their advantage. The result is not perfect competition but a cheater capitalism, in which the rich and powerful feel justified in enjoying their privileged position. The mechanisms of competition as a motivation are driven by the imperial rival states and generally by 
the same imperial system. In the words of Petras (2013b) competition in capitalist terms is mediated, influenced and directed by the states.

To achieve rationality and market efficiency should be associated values of democratic culture such as individual freedom, legal and political equality based on competition, under the reasoning that liberal democracy and capitalism are explained by economic reasons and the struggle for recognition. The relationship between the market and democracy is a tortuous relationship while the principles of political economy which underpin transnational capitalism contradict the principles of democratic theory when certain rights are privileged over others.

This liberal democratic theory is founded on the principles of freedom and equality of individuals, where they become more relevant to the communities and their political identities. Thus, democracy has become the perfect tool to maintain the hegemonic power of globalizing capitalism. Around this principle of liberal democracy there is a debate between liberal multiculturalism positions, democratic socialists and communists. Liberal democracies became more advanced social democracies.

In the eighties and nineties it was used the term "informal economy" whose expansion is related to the structural conditions of transnational capitalism that result in increased poverty and marginalization in the global scope. The size of the informal sector is a good indicator of the quality of external institutions, taking into consideration the costs of structuring relationships with external institutions that are related to the proportion of interactions that ensure the design of domestic institutions.

Long before the term globalization, proposed in 1983 by Theodore Levitt to designate a convergence of global markets, and to refer to an object that is elusive and unmanageable, it was a buzzword to mean economic connections, the world were economically and politically interrelated. The term globalization acquired mid-1990 a media attention in the new international order in 1991 that allowed new ideas to the negative image dragged by capitalism.

In the emerging new world order, the State does not disappear but is disaggregating into distinct parts, separated according to their functionality. A new status of nation states emerged in the stratified world political unipolarity. The State is well in captivity, caught in the web of the interests of the dominant national groups seeking trans-nationalization of capital accumulation by penetrating power structures of global capitalism.

The rise in the less developed countries of a new transnational capitalist class connected to international financial circuits, which under a neoliberal hegemonic project, have become the new economic elite that has been the rise to political power and promoted the interests of imperialist capitalism. The economicpolitical elite and their agents are campaigning to legitimize neoliberal ideology of transnational capitalism that promotes free market.

The rhetoric surrounding the consolidation of the Cold War divided the world according to the degree of development of their economies in those highly developed that made the first world, and those economies that agglutinated around socialism not integrated into the world economy forming the second world. Finally, all other not developed economies were known as the Third World. 
In the times of the Cold War, the world was divided into bipolar democratic nations with the United States at the front and communist nations aligned around the power of Russia.

The fall of the Berlin Wall and the disappointments that caused nationalist economic policies in many nation-states, it was believed that this represented the triumph of liberal democracy around the world. Similarly, the sharp fall of Soviet socialism and the countries of Eastern Europe, of which curiously, Gorbachov has argued that its essence was competition in the Hegelian-Marxist concept. The collapse of communism legitimized democracy as the political system more viable.

At the end of the eighties, the end of the Soviet bloc gave the final push towards consolidation of neoclassical theory as dominant as the only approach to national development increased with growth strategies focused on the state. Those growth strategies of communist states were discredited. The way was clear for the global expansion of capitalism and with it the hegemony of the theoretical school more market oriented.

Therefore, real socialism entered into a period of total decadence, in a crisis of no return. Against the excesses of capitalism, it is necessary to find explanations and teachings of this fall in order to redefine the new forms of organization. While it must be accepted that socialism did not fail completely because undertook significant contributions to the development of the people who experienced it. Moreover, however, the socialism could not resist the ideological attacks of globalizing capitalism.

With the disappearance of the economies around the real socialism and the opening of Communist China, the second world is made up of a set of economies that have a relevant role and form the periphery. The economies of the second world become more profitable for the first world. The development of capitalism globalization with a new geo-economics is expanded to all corners of the globe. These peripheral economies of the second world have competing interests in terms of negotiations for preferences for their economies.

In the world order, two characters appear in capitalism today: first, the use of military power unfettered, and in the second instance the pre-eminence of speculative finance. The defining characteristics of capitalism today are: a) private ownership of the means of production, utilities and strategic natural resources, with a high concentration of multinational companies. b) oligopoly market and dependent on external hegemonic centers, c) extreme commoditization of capitallabor ratio, with the consequent growth of surplus value for the capitalist and the worker's inferiority (Wallerstein, 2001; Amin, 2001, Dietererich, 2002, Galeano, 2002).

The spatial reference of development has moved from the national with the weakening of the nation state to the supranational level and local blocks strengthening regional integration and decentralization of functions to local governments. Only now the phenomenon appears as a true paradigm mounted on several fallacies, myths and slogans that lead to democracy, to the welfare and progress of mankind. A global democratic proposal does not fit local situations and vice versa. Besides, there is a growing tendency to the rights of man and of the 
property and not to the construction and development of a public space (Laïdi, 2000).

Transnational capital has the ability to dissolve its commitment to the welfare of the working class, which regardless of territorial boundaries; it is a reserve for transnational capitalism. So, at this historical juncture, rather than as a characteristic, transnational capital has broad power over the masses. Financial expansion of capitalism which is based on periodic crises, accelerated mobility processes, concentration and financial performance and questioned the monetary policies of national institutions, leading to a restructuring of production systems on a global scale.

The establishment of blocs linked to free trade agreements (FTAs) ("one market, one currency") increases the risk of instability and international competition, until there is - by necessity - a global reference currency, the one of the country that becomes the leader. The crisis of Fordist capitalism found its own limitations and contradictions as a production system with the processes of capitalist accumulation, was the cause that triggered the scientific and technological revolution reorganizing the production system in multinational agencies that promote the globalization processes.

The technological monopoly of transnational corporations concentrates resources and excludes from the benefits to those without the skills to join the processes of scientific and technological revolution. Thus, without the skills are sentenced to a dependency and in the best of the cases, to be mere repeaters. Business and corporate mergers are a trend of the concentration and accumulation of monopoly capital to address the effect of recurring crises of capitalism. The release of capital of rigid Taylorist, Fordist and Keynesian processes facilitates the emergence of a transnational integration of interests and global movements of political economic elites.

However, they are not the only corporate America winners on the board of globalization as a product of the contradictions in the development of neocapitalism, of the tensions generated in all areas of human activity, and the side effects of global markets. These large U.S. corporations increased their reliance on foreign subsidiaries to capture profits through export strategies, so they are the primary stakeholders in promoting the adoption of the principles of free market and neoliberal economics. Global corporations are motivated by establishing branches in all corners of the world where the rules of origin are applied to "local content" to meet the requirements of free trade and its major customers (Dietererich, 2002).

Of the 500 corporations more important in the world, $46 \%$ are from the United States and in less than a decade have increased their profits by 36 to $43 \%$. Eleven of the 13 world's biggest financial houses are controlled by investors from United States, according to Petras (2013a). In the global economy dominate euroestadounidenses companies. $79 \%$ of the 500 largest multinationals are located in the U.S. or Europe. If it is included Japanese corporations, the percentage increases to $91 \%$ (Petras, 2013c). International agreements that are perceived as negative for capturing profits of TNCs and MNCs are rejected, always looking for a justification to "humanitarian purposes." 
The capitalist economic growth is linked to imperialist expansion. In the third phase of expansion of globalizing imperialism, its goals remain the control of world markets and the exploitation of the resources of the less developed countries (LDCs). These processes are linked to multi-secularly deployments in polarizing world capitalism. The processes are also compatible with the logic of imperialism for domination and appropriation of surplus (Saxe-Fernández, 1999). The transfer of this surplus is ensured by the design and implementation of policies in conjunction with global power structures. In this phase, the economic globalization equals to imperialist capitalism expansion of global markets.

\section{THE EMERGENCE OF THE NEW ECONOMY}

In the last three decades of the last century (the twentieth century) globalization processes extended and deepened due to a number of factors, including: The technological revolution with its rapid development of telematics, communications, and rapid innovation science and technology base. The interaction of the revolution in information technology and communication, the crisis of the welfare state and capitalism, and the emergence of new social movements have led to the formation of a new hegemonic social structure that Castells (1998) calls the "society-network ", the new economy based on the informational / global and a new culture on the basis of real virtuality.

Economic globalization is a phenomenon that has resulted in the advancement of information and knowledge technologies (IKT) like telecommunications, through the integration of economic activities that occur mainly in the rapid increase of capital mobility. This increase in international capital mobility, along with the increase of strategic alliances, mergers and acquisitions is one of the characteristics of the economic globalization processes.

The so-called New Economy as a development strategy has largely failed in its expectations. Basically, those profitability criteria are the same as the traditional economy based on advanced industrial capitalism that generates goodwill in favor of capital and against the amount of work and information. In addition, the information tends to substitute capital which it is information itself and therefore also tends to replace the work. Creating virtual capital disappears in the digital world the notion of time as a factor for accumulation. Today, the world is witnessing the third great revolution supported by an expanding capitalist imperialist revolution of economic globalization, which is challenged by those promoting the democratic revolution and the transformation of capitalist appropriation forms of surplus value by other more collective forms.

It is at the local, national and regional levels where it is managed the dynamics of transnational deregulation of markets, so it is considered that capitalism as a system is promoted nationally. In part, national economic policies are adjusted to the pressures of national capitalist elites integrated to networks of transnational capitalism, rather than external pressures of global institutions. The expansion of capitalism took advantage that gave it advantage over the spoiled peripheral economies and their dysfunctions. As an example, the payment of the 
foreign debt of Latin American economies is a priority in their budgets for social spending on education, health, etc.., and infrastructure investments. The support to handle the debt crisis of the least developed countries took advantage of transnational capitalism to impose operating structures and enforce conditions.

The strategy worked perfectly to take hostage to countries that refused to accept the implications of the new global development model. While debt relief is made on behalf of poor countries, they get worse if resources are not correctly applied based on programs that are aimed at achieving economic growth as an end in itself. The weakened culture of dependence of the poor is replaced by the impressive hegemonic project of capitalism expansion encouraged by the economic interests of large corporate groups. This program should give credibility to the economic policy implemented.

As a result, even though the upper classes and their servants in government incur in charging large debts in the seventies and eighties, the lower classes have been bearing the burden of debt repayment during the nineties. Since the midseventies a new stage in the history of world capitalism important layers of the population ever increasing in number observed and increasingly considered as their working and life conditions deteriorate (Bienefeld, 1991).

The capitalist power or hegemony has the resources and the power to impose such rules as the transnational hegemony of global capitalism development through supranational structures. The governments of the imperialist corporations and international financial institutions most influential share a concept of global development and poverty alleviation centered on unlimited economic expansion of open markets and trade liberalization. The nation state has become an instrument of development cooperation of transnational capitalism. If looking at the neoliberal state as a continuation of the welfare state, it means legitimizing the new correlation of social forces arising from the transformations of capitalism and establishes the framework and infrastructure for creating transnational state.

The transnational capitalist elite requires of regulatory processes to stabilize the capitalist system. The economic elites who rule in market democracies conduct intense campaigning to convince global citizenship in the myth of unprecedented power. The superstructure formed by transnational institutions design policies that nation states must implement. In global markets, the interactions between companies and consumers, cultures and capitalisms, transform to homogenize preferences, which causes people to react positively or negatively in the expressions of fundamentalism. For other, divergence and heterogeneity is a valid form of reaction to the marketization of social life and the trade and financial integration.

\section{IMPACT ON LATIN AMERICA}

The formal implementation of this approach in the Latin American states was called structural adjustment and basically consisted of seven steps: the unilateral opening of foreign markets, extensive privatization of state enterprises, deregulation of goods, services and labor markets, capital market liberalization, 
with an extensive privatization of pension funds, fiscal adjustment based on a drastic reduction of public spending, restructuring and thinning of social programs supported by the state with a focus $d$ compensatory schemes for the most needy and to industrial policy and any other form of state capitalism and concentration of macroeconomic management (Portes, 1997).

Countries undergoing structural adjustment program accepted institution building related to the interests of transnational capitalism. Structural reforms in labor and social policies encourage de-commoditization, while globalizing capitalism relegated to the role of state attention to sectors excluded by a more competitive labor market and flexible production systems through the hypothesis of inequality compensation levels. This legitimizes the economic and social inequality of capitalism under the guise of development (Thomas, 1989).

The global economy has a tendency to increase productivity levels based on scientific and technological innovation, cheap and flexible labor has to adapt to the conditions of international competitiveness. The mobility of labor has not been liberalized, despite the potential benefits that would bring discipline to the domain of the free market. Since national and local companies lack the means to compete on equal terms with transnational capitalism, they have little choice other than to become the local junior partners.

Galeano (2002) recounts the realism of capitalism in Latin America as economic and political system of laocca when he argues in a conference that unemployment is a hard problem. Today we can do twice as many cars with the same number of people. When it comes to improving the educational level of the population, as a solution to the unemployment problem, he always says that he is worried about the memory of what happened in Germany: there education was advertised as a remedy to unemployment, and the result was frustration of hundreds of thousands of professionals who were pushed to socialism and rebellion. I find it hard to say, but I wonder if it would be better for the unemployed act with clarity and leave to find work directly to McDonald's.

Employment is the means of access to markets. Price controls appear to be problems of the past, but terrorism has resurfaced. Above all, the richest countries are also those with the best brands in the business.

\section{CRITICAL ANALYSIS OF THE EFFECTS OF CAPITALISM}

A critical analysis of the effects of capitalism reveals that created extreme inequalities in the region and worldwide. Those who earned more from the processes of globalization are those that changed their policies to be inserted, than those who did not, according to Lindert and Williamson (2001). Pritchett (1996) recommends forgetting convergence because the evidence suggests that the predominant theme of the modern economy is a massive divergence in per capita between rich and poor, a gap that continues to grow yet.

In other words, globalization is deepening dependency relations and development between the peoples of the world through processes that are of looting, plundering and devastation of natural, human and financial resources. In 
this regard, Gonzalez Casanova (1997) said that the current globalization reformulates and maintains dependence structures of colonial origin, the equally strong imperialism of the late twentieth century, and the central and peripheral capitalism that was organized between 1930 and 1980.

Moreover, the globalization of capitalism also globalizes misery, even though its aim is reducing the level and severity of poverty by taking advantage of this phenomenon. Clearly, not so much the amount of resources determines the level of poverty in a country but is uses of resources. Poverty has many dimensions, from which they are always hungry, to the lack of development opportunities and lack of access to basic infrastructure, such as lighting, water, etc., to psychological aspects such as impotence, humiliation and dependency. An estimated $\mathbf{4 0}$ million people die of hunger every year.

In the capitalist system, democracy has serious problems of legitimacy. Covertly legitimate liberal democracy to capitalism in the domain of man by man through the process of developing legal rules to implement the economic policies formulated in the best interest of the structures of economic power of large corporations and transnational speculative financial capital that dominate the international market. They rely on the decisions of the technocrats of undemocratic international financial institutions to impose their guidelines to governments with the consequent loss of sovereignty.

The role of the democratic state conflicts with postindustrial capitalism globalization between the processes of commoditization and de-commoditization of social policy. What we are witnessing is a radical change of industrial capitalism to a postindustrial conception of economic relations. Nevertheless, as a result of the implementation of programs of economic liberalization, society is polarized reflecting the contradictions of industrial capitalism, to the point where it becomes a dual society in which few have access to the benefits of age information, while others are totally excluded. The processes of neoliberal globalization increases social inequalities that weaken the democratic system sharpen the contradictions and make it incompatible with capitalism.

In the latter part of the twentieth century that balance was broken in favor of markets and here is the result: the loss of public confidence, counterfeiting and fraud destroy capitalism and the free market, and in the long-term the foundations of our society. This has not been said by any dangerous leftist, but by the Federal Reserve former chairman, Alan Greenspan. Did also exaggerates Greenspan? The world systems theory focuses on the study of the social system and their interrelations with the advance of global capitalism as driving forces between the different countries, including the small.

Despite the hegemony of the capitalist system continues to grow, in the last two decades the global economy is constantly deflation threatening large investments from U.S. imperial and capitalist hegemonic interests. Already these interests are in tension and confrontation for a locus of power to maintain an advantageous position that allows them to accelerate capital accumulation. The U.S. imperial strategy to reverse the trend of decline of hegemonic capitalism has caused more instability to the global economy and thus some geopolitical 
arrangements that portend the imminent fall of the imperial hegemony of capitalism.

The crisis of the object capitalism falls more in the realm of use value rather than exchange value. Signs of exhaustion of neoliberalism were presented from regional financial crises started with Mexico in 1994 and the chaos caused by the dynamics of the new economy that tried to be the locomotive of the global economy entered in crisis in 2001. High levels of economic speculation determine vulnerability of the economic system.

It is enough that a national institution has financial difficulties to drag after it a broad sectors and beyond the frontiers, making the regional phenomenon. But the end of the economic crisis means the recovery of the beneficiaries of capitalism and a serious decline in living standards and social benefits of the working classes. The future of workers is very uncertain. The crisis of the object capitalism is presented more in the domain of their use value that in the domain of exchange value.

\section{QUESTIONS TO NEOLIBERAL ECONOMIC GLOBALIZATION PROCESSES.}

New social movements against neoliberal globalization, starting from Seattle, consolidate theoretical and practical exhaustion of neoliberalism and question both the effectiveness of these policies as its claim to be the only viable development path. The global justice movement has its roots in the past 20 years in the least developed countries, although there is strong rebellion since Seattle in 1999 in developed countries as a democratization movement that is opposed to the imposition of neoliberal policies. With the ideological crisis of neoliberalism that has implications for the economic and social crisis that weakens the political systems, questioning the free market principles, are promoted civil society actions and claimed the complementary roles of the state. The struggle against neoliberalism is also against the commoditization of the world.

Proponents of global capitalism argue that if the conditions of law and order are maintained, the economic welfare of society will increase, because it is more consistent with human nature, they argue. However, globalizing capitalism is inherently polarizing development of peoples, while being threatened by low economic growth. A critical analysis of the effects of capitalism reveals that it has created extreme inequalities in the region and worldwide. The economic and social inequalities among the world's advanced countries and many Third colonial and semi-colonial worlds are persistent.

The checks and balances are bonds, alternative experiences, establishing solidarity between people. The checks and balances are the many instances in which policy is developed. They are counter-posed fundamental questions about how the world is building capitalism. Forums become symbolic places that are manifested and expressed in the various counter movements in convergence or resistance, with joints from the same basis. The multiplicity of social movements is its strength and what most fear the project of hegemonic ideology of capitalism. Social movements have a role in the findings of a comprehensive response by 
establishing transnational networks that after mitigate imaginable ethnocentric inclinations; can provide a counterbalance to the globalization of neoliberal capitalism.

The activities of these organizations pose no danger or risk to the power structures of economic and political elites, for the nation state, to international financial institutions, to the imperialist states and transnational corporations. At the heart of the counter-powers develop new strengths, new demands, new political practices, new forms of struggle and life. The drive and creativity are vital in counter-powers (Proceso, 2001). Historically capitalism shows some contradictions that limit growth and threatening the mythology containment policy to enter an uncontrollable crisis of collective empire and to avoid it requires alternative models for a new world order in much will depend on the emerging forces in opposition to the new global colonialism that fits in a cynical, repressive and exclusionary political ideology.

Despite the emergence of a plurality of critical thinking processes in globalization that speak of alternative models, it has not materialized a social organization different from the one that the market-based capitalism promotes. Critical thinking has to consider in theory and experience the weaknesses of capitalism and the design of a new world order as an alternative analysis from the local to the global policy. It should be facilitated by adequate, new practices and strategies of social movements oriented towards the anti systemic design of a democratic and sovereign alternative.

\section{CONCLUSION}

This analysis reaches the conclusion that the primary cause of the extreme social and economic inequality in anywhere in the world, as it could be in Latin America, is the result of the expansion of capitalism in the world. Thus, contemporary Latin American economies have become an integral part of the new global economic system that is not dominated by nation-states but by large transnational corporations that are major global players in this system. In other words, transnational capitalism has influenced institutions and organizations.

Neoliberal ideology has been used to justify the strategy of restructuring policies and economic adjustment followed in most Latin American countries since the eighties. In fact, globalization processes stimulated by the global expansion of capitalism and development have consistently favored only a limited proportion of the Latin American population while the majority has to suffer the adverse effects of this process. In other words, it is the subsidiary state, properly a neo-liberal model dependent peripheral capitalism, the dominant ideology and practice in the last 33 years.

It is needed an organizational cultural transformation for not accepting the forms of domination, power and alignment of globalizing capitalism and to reconstruct the identity of communities, institutions and organizations through individual and collective action claiming self-determination, independence and self-management. Capitalism, by itself, has no ethical value. This does not mean 
that there are no moral capitalist. Morals and Ethics are not synonymous when applied to individuals in institutions and organizations. Its moral molded into human nature towards individualistic and naked singularities most harrowing miseries of men when its project of power has no ethical limits in institutions and organizations.

One solution to break America's dependency relationship is to develop a protectionist capitalism within a trading bloc that facilitates transnational formation of institutions and organizations under different ownership and new forms of governance and under a development strategy that Dietererich (2002) termed as creating research, production and global marketing complex (RPMC), which can be achieved by the union of holdings, part of the global surplus in its market segment.

\section{REFERENCES}

Aguirre Rojas, C. A. (2000). Para una crítica del concepto de globalización. Revista Theomai, Número 2, segundo semestre del 2000.

Amin, S. (2001). Imperialismo y globalización. Retrived from http://www.rcci.net/globalización/2001/fg175.htm

Bienefeld, M. (1991). Karl Polanyi and the contradictions of the 1980s. en Mandell M. Y Salée D., edits., The Legacy of Karl Polanyi, Londres, MacMillan.

Castells, M. (1998). ¿Hacia el estado red? Globalización económica e instituciones políticas en la era de la información", en Seminario Internacional sobre Sociedade e Reforma do Estado. Brasilia: Mare.

Cemy, P. G. and Evans, M. (2004). Globalization and public policy under New labour. Policy Studies, Volume 25, Issue 1. Pages 51-65.

Cemy, P. G. and Evans, M. (2000). New Labour, Globalization, and the Competition State. Centerfor European Studies Working Paper Series \#70. Harvard University.

Centro Tepoztlán, AC (1999). Pobreza, exclusión y estrategias de desarrollo. Revista Este País, número 99, junio.

Chase-Dunn, Ch. K. (2001). Globalization. A world systems perspective in Ciprut, J. V. (Ed.) Of fears and foes: security and insecurity in an evolving global political. Greenbook Publishing Group.

Dietererich S. H. (2002). Libertad de comercio, apología y oportunismo. El Universal, Sábado 03 de agosto de 2002.

Galeano. (2002). Patas arriba. La escuela del mundo al revés. Madrid, Siglo XXI.

González Casanova, P. (1997). Globalidad, neoliberalismo y democracia. En González Casanova y Saxe-Fernández (coordinadores). El mundo actual: Situación y alternativas. UNAM-CEIICH, México.

Grosfoguel, R. and Cervantes-Rodríguez, A. M. (2002). The modern/colonial/capitalist world-system in the Twentieth century: Global processes, anti-systemic movements, and the geopolitics of knowledge. Praeger Publishers. 
Hayek F. A. (1975). Full employment at any price. London: Institute of Economic Affairs.

Jay, E. and Jay, R. (1986). Critics of capitalism. Victorian reactions to political economy. Cambridge University Press.

Laïdi, Z. (2000). El desafío de la hipermundialización. Nexos No. 268, abril.

Lindert, P. H. and Williamson, J. G. (2001). Does globalization make the world more unequal? NBER Working Paper no. 8228, April 2001.

Lovins, A. B., Lovins, L. H and Hawken, P. (1999). A road map for natural capitalism. Harvard Business Review, May-June 1999.

Mann, M. (2001-2002). Globalization Is (Among Other Things) Transnational, Inter-National and American. Science \& Society. Vol. 65, No. 4 (Winter, 2001/2002), pp. 464-469.

Márquez Ayala, D. (2000). Globalización...¿Cuál? La Jornada, mayo 5.

Mooers, C. (1991). The making of bourgeouis Europe: Absolutism, revolution, and the rise of capitalism in England, France and Germany, Verso, New Left Books.

Nelson, R. R. (1990). Capitalism as an engine of progress. Research Policy, Vol. 19, Issue 3, June 1990, 193-214

Ong, A. (2007). Boundary crossings: Neoliberalism as a mobile technology Trans Inst Br Geogr NS 32 3-8 2007.

Petras, J. (2013a). El imperialismo resurgente: el problema principal del nuevo milenio. Mimeo.

Petras, J. (2013b). Centralidad del estado en el mundo actual. La Página de Petras, 26 de mayo del 2013, http://www.rebelión.org/petrascentralidad.htm

Petras, J. (2013c). El mito de la tercera revolución científico-tecnológica en la era del imperio neo-mercantilista. La página de Petras, 26 de mayo de 2013,

http://www.eurosur.org/rebelion/petras/revcient280701.htm.

Portes, A. (1999). Capital social: sus orígenes y aplicaciones en la sociología moderna. En: Carpio, Jorge y Novaconvsky, Irene (comp..) De igual a igual. El desafío del Estado ante los nuevos problemas sociales. Fondo de Cultura económica-Siempro-Flacso. México. Pp. 243-266.

Pritchett, L. (1996). Forget convergence: Divergence past, present and future. Finance and Development (June, 1996):40.

Proceso (2001). Los contrapoderes de la globalización neoliberal. Revista Proceso No. 1277, 22 de abril del 2001.

Reich, S. (1998). What is globalization? Four posible answers. Working Paper \#261 The Helen Kellogg Institute for International Studies, December 1998.

Robinson, W. I, and Harris, J (2000). Towards a global ruling class? Globalization and the transnational capitalist class. Science \& Society; Spring 2000; 64, $11-54$

Saxe-Fernández, J. (2000). Etrevista realizada por K. Moreno. Inédita. Abril 2000.

Schumpeter, J. (1994). Capitalism, Socialism and Democracy. Routledge.

Soros, G. (2002). Washington intenta minimizar daños de fraudes, advierte Soros: en EU todos somos cómplices de la crisis", traducción de Jorge Anaya, La Jornada, 4 de Septiembre del 2002.

Thomas C. (1989). Restructuring the World economy and its political implications for the Third World. in: Instability and change in the World economy, 
Edited by MacEwan and W. Tabb. New York: Monthly review Press. pp. 340-356

Thomas, J. M. (1980). Revivalism and cultural change: Christianity, nation building and the market in the Nineteenth century United States. University of Chicago Press.

Tormey, (2012). Anti-capitalism. Wiley-Blackwell Encyclopedia of Globalization. DOI: 10.1002/9780470670590.wbeog025

Wallerstein, I. M. (2001). Unthinking social science. The limits of Nineteenth Century paradigms. Temple University Press.

Weber, M. (1978). Economy and society. (G. Roth \& C. Wittich, Eds.). Berkeley: University of California Press.

Submetido em 31/06/2013

Aprovado em 16/08/2013

\section{Sobre o autor}

José G. Vargas-Hernández

M.B.A.; Ph.D. Research Professor University Center for Economic and Managerial Sciences University of Guadalajara.

Periférico Norte 799 Edificio G-306 Zapopan, Jalisco C.P. 45100 - México.

E-mail: jvargas2006@gmail.com 